\title{
Hydrolysis of cupric chloride in aqueous ammoniacal ammonium chloride solutions ${ }^{\left({ }^{(0)}\right.}$
}

\author{
J.L. $\operatorname{Limpo}^{(*)}$, A. $\operatorname{Luis}^{(*)}$ and M.C. Cristina ${ }^{(*)}$ \\ Abstract Cupric solubility in the $\mathrm{CuCl}_{2}-\mathrm{NH}_{4} \mathrm{Cl}-\mathrm{NH}_{3}-\mathrm{H}_{2} \mathrm{O}$ system for chloride concentrations lower than 4 \\ molal in the temperature range $25-60{ }^{\circ} \mathrm{C}$ was studied. The experimental results show that for chloride \\ concentration between 3.0 and 1.0 molal the cupric solubility is determined by the solubility of the \\ cupric hydroxychloride $\mathrm{Cu}(\mathrm{OH})_{1.5} \mathrm{Cl}_{0.5}$. For a chloride concentration value of 4.0 molal, there are two \\ cupric compounds, the hydroxychloride $\mathrm{Cu}(\mathrm{OH})_{1.5} \mathrm{Cl}_{0.5}$ or the diammine chloride $\mathrm{Cu}\left(\mathrm{NH}_{3}\right)_{2} \mathrm{Cl}_{2}$, on \\ which the solubility of $\mathrm{Cu}(\mathrm{II})$ depends, according to the temperature and the value of the ratio \\ $\left[\mathrm{NH}_{3}\right]_{\text {Total }} /[\mathrm{Cu}]_{\text {Total }}$.
}

Keywords: Solubility. Cupric diammine chloride. Cupric hydroxychloride. Ammoniacal ammonium chloride solutions.

\section{Hidrólisis del cloruro cúprico en soluciones acuosas amoniacales de cloruro amónico}

\begin{abstract}
Resumen Se estudia la solubilidad del $\mathrm{Cu}(\mathrm{II})$ en el sistema $\mathrm{CuCl}_{2}-\mathrm{NH}_{4} \mathrm{Cl}_{-}-\mathrm{NH}_{3}-\mathrm{H}_{2} \mathrm{O}$ para concentraciones de cloruro inferiores a 4 molal en el intervalo de temperaturas $25-60^{\circ} \mathrm{C}$. Los resultados experimentales muestran que, para concentraciones de cloruros comprendidas entre 3,0 y 1,0 molal, la solubilidad cúprica viene determinada por la solubilidad del hidroxicloruro cúprico, $\mathrm{Cu}(\mathrm{OH})_{1,5} \mathrm{Cl}_{0,5}$. Para concentraciones de cloruro 4,0 molal, existen dos compuestos cúpricos, el hidroxicloruro, $\mathrm{Cu}(\mathrm{OH})_{1,5} \mathrm{Cl}_{0,5}$ o el cloruro de diamina, $\mathrm{Cu}\left(\mathrm{NH}_{3}\right)_{2} \mathrm{Cl}_{2}$, de los que, de acuerdo con la temperatura y con el valor de la relación $\left[\mathrm{NH}_{3}\right]_{\text {Total }} /[\mathrm{Cu}]_{\text {Total }}$, depende la solubilidad del $\mathrm{Cu}(\mathrm{II})$.

Palabras clave: Solubilidad. Cloruro cúprico diamina. Hidroxicloruro cúprico. Soluciones amoniacales de cloruro amónico.
\end{abstract}

\section{INTRODUCTION}

During the last years, attention has been given to the ammonium chloride based hydrometallurgical processes. Aqueous solutions of high concentration of ammonium chloride are a very interesting leaching medium, being especially appropriate for the treatment of complex raw materials of both oxide and sulphide types (1-6). The use of this leaching medium is appropriate for the recovery of metals such as $\mathrm{Zn}, \mathrm{Cu}, \mathrm{Pb}, \mathrm{Hg}$ and $\mathrm{Ag}$. During the leaching with ammonium chloride solutions, besides the solubilization of these metals, ammonia is produced in the proportion of 2 mols of ammonia

\footnotetext{
(•) Trabajo recibido el día 20 de septiembre de 1994.

(*) Centro Nacional de Investigaciones Metalúrgicas
} (CSIC). Avda. de Gregorio del Amo, 8. 28040-Madrid (Spain). per mol of dissolved metal for the oxides of divalent metals (3 and 4), and in a somewhat lower proportion for the sulphides. This proportion varies according to the mineral species of sulphide being leached (7). Therefore, the resultant medium of the leaching step is, in both cases, an aqueous ammoniacal ammonium chloride solution.

Chlorides of metals such as copper and zinc have a high solubility in concentrated ammonium chloride solutions. This solubility is drastically reduced in the presence of ammonia, due to the precipitation of the diammine chlorides. The solubility of the diammine chloride of these metals is heavily influenced by both the composition of the solution and the temperature (8 and 9). For process development purposes, it is necessary to have a detailed knowledge of the solubility of these metal chlorides as a function of temperature and solution composition. In a previous study by the present 
authors (9), the solubility of cupric chloride in concentrated solutions of ammonium chloride in the presence of ammonia was studied. The results there obtained showed that, for the studied ammonium chloride concentration range (total concentration of chloride between 5 and 9 molal), the cupric solubility is restricted by either the solubility of the cupric diammine chloride or the cupric hydroxychloride.

When the concentration of ammonium chloride decreases below 5 molal, $\mathrm{Cu}(\mathrm{II})$ solubility diminishes. The knowledge of $\mathrm{Cu}(\mathrm{II})$ solubility in the $\mathrm{CuCl}_{2}-\mathrm{NH}_{4} \mathrm{Cl}-\mathrm{NH}_{3}-\mathrm{H}_{2} \mathrm{O}$ system for these lower ammonium chloride concentrations is also a very important matter for a suitable hydrometallurgical use of this leaching medium. Especially, these solubility data must be considered to avoid metal losses in pulp washing steps. No literature on $\mathrm{Cu}$ (II) solubility in these conditions of low ammonium chloride concentration has been found. The present study investigates this matter.

\section{EXPERIMENTAL RESULTS}

The range of conditions considered in this study corresponds to the ammonium chloride concentrations lower than 5 molal and low or relatively low concentrations of ammonia. The total concentration of chlorides was varied between 1 and 4 molal. Solubility was studied for the temperatures of 25 and $60^{\circ} \mathrm{C}$.

The experimental technique used, as previously described (8 and 9), consisted in determining, at each selected temperature, the compositions of the different saturated solutions in equilibrium with the respective solid phases. Copper was analyzed by atomic absorption spectrometry, ammonia by back titration, adding an excess of standardized hydrochloric acid solution and titrating with standardized $\mathrm{NaOH}$ using dimethyl yellow as an indicator, and chloride by the Volhard method. Synthetic solutions were used as a basis, and analytical grade chemical reagents were used in their preparation. Solutions were prepared with concentrations higher than those permitted by the solubility at the chosen temperature. For this purpose, solutions very near saturation were prepared at temperatures above those of each test, achieving over-saturation on cooling to the test temperature. To ensure that crystallization was complete and equilibrium had been achieved in all cases, a period of $2 \mathrm{~h}$ was always allowed to pass, with gentle agitation, at the chosen constant temperature. This time was considered sufficient after checking that there were no variations in the composition of the solution for times longer than 1 $h$. The solid was removed from the liquid phase by filtration, wiped by pressing between filter papers, without washing, and dried at room temperature. Chemical analysis and X-ray diffraction were used to monitor the compositions of the solid phase.

Chemical analysis of crystallized solids showed the existence of two different compounds, with compositions corresponding to the diammine chloride of formula $\mathrm{Cu}\left(\mathrm{NH}_{3}\right)_{2} \mathrm{Cl}_{2}$ and the oxychloride of formula $\mathrm{Cu}(\mathrm{OH})_{1,5} \mathrm{Cl}_{0,5}$. The analytical values obtained for these solid specimens differed something from the theoretical values according to these formulae. The differences obtained were very light for the diammine chloride and more important for the oxychloride. They were caused by contamination with $\mathrm{NH}_{4} \mathrm{Cl}$ because of not washing the solid phase and quantitatively agree with the amount of solution imbibed in each solid compound.

Analysis of solid phases by X-ray diffraction showed that in the range studied three different compounds crystallize. For the solids characterized by chemical analysis as diammine cupric chloride of formula $\mathrm{Cu}\left(\mathrm{NH}_{3}\right)_{2} \mathrm{Cl}_{2}$, their diffractograms coincided with that reported in (10) for this compound. The X-ray analysis of the solids characterized by chemical analysis as oxychloride showed that all these solids are mainly constituted by a same compound, whose diffractogram coincides with that reported in (10) for the $\mathrm{Cu}$ (II) chloride hydroxide hydrate of formula $\mathrm{Cu}_{7} \mathrm{Cl}_{4}(\mathrm{OH})_{10}\left(\mathrm{H}_{2} \mathrm{O}\right)$. In the major part of these solids, this compound appears as the unique constituent. In the rest, together with the diffractogram lines of this compound, appear other lines that coincided with those reported in (10) for the $\mathrm{Cu}$ (II) chloride hydroxide (botallackite) of formula $\mathrm{Cu}_{2} \mathrm{Cl}(\mathrm{OH})_{1,5}$. Careful chemical analysis of the solids, whose diffractogram coincides with that reported in (10) for the $\mathrm{Cu}_{7} \mathrm{Cl}_{4}(\mathrm{OH})_{10}\left(\mathrm{H}_{2} \mathrm{O}\right)$, points out that its composition is lightly different to that corresponding to this formula, being however in agreement with the formula $\mathrm{CuCl}_{0,5}(\mathrm{OH})_{1,5}$.

Table I sets out the experimental solubility results. The composition of the solution and the solid phase in equilibrium is given for each temperature studied.

\section{DISCUSSION OF RESULTS}

In a previous work (9), $\mathrm{Cu}$ (II) solubility in the $\mathrm{CuCl}_{2}-\mathrm{NH}_{4} \mathrm{Cl}-\mathrm{NH}_{3}-\mathrm{H}_{2} \mathrm{O}$ system was studied for the high ammonium chloride concentrations. The results there obtained showed that, for total chloride concentrations higher than 5 molal, $\mathrm{Cu}$ (II) solubility is restricted by either the solubility of the cupric diammine chloride or the cupric oxychloride. In all the range of experimental conditions there 
Table I.- $\mathrm{Cu}(\mathrm{II})$ solubility data in the $\mathrm{CuCl}_{2}-\mathrm{NH}_{4} \mathrm{Cl}-$ $\mathrm{NH}_{3}-\mathrm{H}_{2} \mathrm{O}$ system

TABLA I.- Solubilidad del Cu(II) en el sistema $\mathrm{CuCl}_{2}-\mathrm{NH}_{4} \mathrm{Cl}-\mathrm{NH}_{3}-\mathrm{H}_{2} \mathrm{O}$

\begin{tabular}{|c|c|c|c|c|c|}
\hline \multirow[t]{2}{*}{ No. } & \multirow{2}{*}{$\underset{{ }^{\circ} \mathrm{C}}{\text { Temp. }}$} & \multicolumn{3}{|c|}{$\begin{array}{l}\text { Solution composition } \\
\text { (mol/kg water) }\end{array}$} & \multirow{2}{*}{$\begin{array}{l}\text { Solid } \\
\text { phase }\end{array}$} \\
\hline & & Chloride & $\mathrm{Cu}$ & $\mathrm{NH}_{3}$ & \\
\hline 1 & 60 & 3,96 & 0,0560 & 0,1550 & A \\
\hline 2 & $"$ & 3,92 & 0,0348 & 0,0209 & $A+B$ \\
\hline 3 & $"$ & 3,94 & 0,0245 & 0,0245 & $\mathrm{~A}$ \\
\hline 4 & $"$ & 4,00 & 0,0592 & 0,0170 & A \\
\hline 5 & $"$ & 4,00 & 0,0506 & 0,0158 & A \\
\hline 6 & $"$ & 3,96 & 0,0396 & 0,0162 & A \\
\hline 7 & $"$ & 4,02 & 0,0294 & 0,0205 & A \\
\hline 8 & $"$ & 4,02 & 0,0480 & 0,1250 & $\mathrm{~A}+\mathrm{B}$ \\
\hline 9 & $"$ & 2,99 & 0,0857 & 0,2620 & $\mathrm{~A}$ \\
\hline 10 & $"$ & 3,01 & 0,0719 & 0,2130 & A \\
\hline 11 & $"$ & 2,95 & 0,0633 & 0,1850 & A \\
\hline 12 & $"$ & 2,99 & 0,0502 & 0,1480 & $\mathrm{~A}$ \\
\hline 13 & $"$ & 2,96 & 0,0331 & 0,0933 & $A+B$ \\
\hline 14 & $"$ & 2,97 & 0,0194 & 0,0470 & $A+B$ \\
\hline 15 & $"$ & 2,99 & 0,0118 & 0,0198 & $A+B$ \\
\hline 16 & $"$ & 3,01 & 0,0642 & 0,0105 & A \\
\hline 17 & $"$ & 2,98 & 0,0569 & 0,0080 & A \\
\hline 18 & $"$ & 2,99 & 0,0424 & 0,0064 & $\mathrm{~A}$ \\
\hline 19 & $"$ & 2,98 & 0,0282 & 0,0096 & A \\
\hline 20 & $"$ & 2,98 & 0,0104 & 0,0131 & A \\
\hline 21 & $"$ & 1,97 & 0,0160 & 0,0420 & A \\
\hline 22 & $"$ & 1,98 & 0,0223 & 0,0655 & $A+B$ \\
\hline 23 & $"$ & 1,99 & 0,0160 & 0,0436 & $A+B$ \\
\hline 24 & $"$ & 2,02 & 0,0379 & 0,1140 & $A+B$ \\
\hline 25 & $"$ & 2,03 & 0,0522 & 0,1610 & $\mathrm{~A}$ \\
\hline 26 & $"$ & 1,97 & 0,0305 & 0,1010 & A \\
\hline 27 & $"$ & 2,00 & 0,0328 & 0,0075 & A \\
\hline 28 & $"$ & 2,00 & 0,0154 & 0,0068 & A \\
\hline 29 & $"$ & 2,00 & 0,0063 & 0,0109 & $\mathrm{~A}$ \\
\hline 30 & $"$ & 2,01 & 0,0542 & 0,0090 & $A+B$ \\
\hline 31 & $"$ & 1,00 & 0,0649 & 0,2600 & $A+B$ \\
\hline 32 & $"$ & 0,98 & 0,0083 & 0,0311 & $\mathrm{~A}$ \\
\hline 33 & $"$ & 0,97 & 0,0209 & 0,0800 & A \\
\hline 34 & $"$ & 0,98 & 0,0029 & 0,0094 & A \\
\hline 35 & $"$ & 0,98 & 0,0351 & 0,0080 & A \\
\hline 36 & $"$ & 0,97 & 0,0221 & 0,0058 & $\mathrm{~A}$ \\
\hline 37 & $"$ & 0,97 & 0,0124 & 0,0032 & A \\
\hline 38 & 25 & 3,95 & 0,0320 & 0,0970 & $\mathrm{Cu}\left(\mathrm{NH}_{3}\right)_{2} \mathrm{Cl}_{2}$ \\
\hline 39 & $"$ & 3,97 & 0,0213 & 0,0584 & $\mathrm{Cu}\left(\mathrm{NH}_{3}\right)_{2} \mathrm{Cl}_{2}$ \\
\hline 40 & $"$ & 3,95 & 0,0157 & 0,0350 & $\mathrm{Cu}\left(\mathrm{NH}_{3}\right)_{2} \mathrm{Cl}_{2}$ \\
\hline 41 & $"$ & 3,91 & 0,0229 & 0,0237 & $\mathrm{~A}$ \\
\hline 42 & $"$ & 3,93 & 0,0549 & 0,0127 & $\mathrm{~A}$ \\
\hline 43 & $"$ & 3,95 & 0,0467 & 0,0125 & A \\
\hline 44 & $"$ & 3,95 & 0,0381 & 0,0149 & A \\
\hline 45 & $"$ & 3,99 & 0,0273 & 0,0174 & A \\
\hline 46 & $"$ & 2,97 & 0,0775 & 0,2440 & A \\
\hline 47 & $"$ & 2,99 & 0,0686 & 0,2070 & A \\
\hline 48 & 25 & 2,95 & 0,0582 & 0,1770 & A \\
\hline 49 & " & 2,97 & 0,0474 & 0,1410 & A \\
\hline 50 & $"$ & 2,96 & 0,0296 & 0,0873 & $A+B$ \\
\hline 51 & " & 2,97 & 0,0177 & 0,0462 & $A+B$ \\
\hline
\end{tabular}

(Continúa)

\begin{tabular}{|c|c|c|c|c|c|}
\hline \multirow{2}{*}{ No. } & \multirow{2}{*}{$\begin{array}{c}\text { Temp. } \\
{ }^{\circ} \mathrm{C}\end{array}$} & \multicolumn{3}{|c|}{$\begin{array}{c}\text { Solution composition } \\
\text { (mol/kg water) }\end{array}$} & \multirow{2}{*}{$\begin{array}{c}\text { Solid } \\
\text { phase }\end{array}$} \\
\cline { 3 - 5 } & & Chloride & $\mathrm{Cu}$ & $\mathrm{NH}_{3}$ & \\
\hline 52 & $"$ & 2,97 & 0,0090 & 0,0182 & $\mathrm{~A}+\mathrm{B}$ \\
53 & $"$ & 2,98 & 0,0615 & 0,0080 & $\mathrm{~A}$ \\
54 & $"$ & 2,98 & 0,0543 & 0,0060 & $\mathrm{~A}$ \\
55 & $"$ & 2,97 & 0,0414 & 0,0064 & $\mathrm{~A}$ \\
56 & $"$ & 2,98 & 0,0266 & 0,0084 & $\mathrm{~A}$ \\
57 & $"$ & 2,98 & 0,0084 & 0,0093 & $\mathrm{~A}$ \\
58 & $"$ & 1,95 & 0,0129 & 0,0366 & $\mathrm{~A}$ \\
59 & $"$ & 1,97 & 0,0195 & 0,0612 & $\mathrm{~A}+\mathrm{B}$ \\
60 & $"$ & 1,99 & 0,0153 & 0,0416 & $\mathrm{~A}+\mathrm{B}$ \\
61 & $"$ & 2,00 & 0,0329 & 0,1070 & $\mathrm{~A}+\mathrm{B}$ \\
62 & $"$ & 2,02 & 0,0498 & 0,1560 & $\mathrm{~A}$ \\
63 & $"$ & 1,97 & 0,0300 & 0,0990 & $\mathrm{~A}+\mathrm{B}$ \\
64 & $"$ & 2,00 & 0,0302 & 0,0054 & $\mathrm{~A}$ \\
65 & $"$ & 1,98 & 0,0141 & 0,0051 & $\mathrm{~A}$ \\
66 & $"$ & 2,01 & 0,0049 & 0,0084 & $\mathrm{~A}$ \\
67 & $"$ & 2,01 & 0,0542 & 0,0090 & $\mathrm{~A}+\mathrm{B}$ \\
68 & $"$ & 0,99 & 0,0190 & 0,0025 & $\mathrm{~A}$ \\
69 & $"$ & 0,99 & 0,0640 & 0,2580 & $\mathrm{~A}+\mathrm{B}$ \\
70 & $"$ & 0,97 & 0,0075 & 0,0297 & $\mathrm{~A}$ \\
71 & $"$ & 0,96 & 0,0188 & 0,0758 & $\mathrm{~A}$ \\
72 & $"$ & 0,97 & 0,0026 & 0,0086 & $\mathrm{~A}$ \\
73 & $"$ & 0,98 & 0,0319 & 0,0044 & $\mathrm{~A}$ \\
74 & $"$ & 0,97 & 0,0205 & 0,0041 & $\mathrm{~A}$ \\
75 & $"$ & 0,97 & 0,0118 & 0,0026 & $\mathrm{~A}$ \\
\hline
\end{tabular}

$\mathrm{A}=$ Solid compound characterized by chemical analysis as $\mathrm{Cu}$ (II) hydroxide chloride of formula $\mathrm{CuCl}_{0,5}(\mathrm{OH})_{1,5}$ and whose X-ray diffractogram coincides with that reported in (10) for the $\mathrm{Cu}(\mathrm{II})$ hydroxide chloride hydrate of formula $\mathrm{Cu}_{7} \mathrm{Cl}_{4}(\mathrm{OH})_{10}\left(\mathrm{H}_{2} \mathrm{O}\right)$.

$\mathrm{A}=$ Compuesto sólido caracterizado por análisis químico como hidroxicloruro cúprico de formula $\mathrm{CuCl}_{0,5}(\mathrm{OH})_{1,5} y$ cuyo difractograma de rayos $X$ coincide con el dado en (10) para el hidrato del hidroxicloruro de fórmula $\mathrm{Cu}_{7} \mathrm{Cl}_{4}(\mathrm{OH})_{10}\left(\mathrm{H}_{2} \mathrm{O}\right)$.

$\mathrm{B}=$ Solid compound characterized by chemical analysis as $\mathrm{Cu}$ (II) hydroxide chloride of formula $\mathrm{CuCl}_{0,5}(\mathrm{OH})_{1,5}$ and whose X-ray diffractogram coincides with that reported in (10) for the $\mathrm{Cu}(\mathrm{II})$ hydroxide chloride (botallackite) of formula $\mathrm{Cu}_{2} \mathrm{Cl}(\mathrm{OH})_{3}$.

$\mathrm{B}=$ Compuesto sólido caracterizado por análisis químico como hidroxicloruro cúprico de formula $\mathrm{CuCl}_{0,5}(\mathrm{OH})_{1,5}$ y cuyo difractograma de rayos $X$ coincide con el dado en (10) para el hidroxicloruro (botallackite) de formula $\mathrm{Cu}_{2} \mathrm{Cl}(\mathrm{OH})_{3}$.

studied (5 to 9 molal), the $\mathrm{Cu}$ (II) diammine chloride is generally the solid phase whose solubility regulates that of the cupric ion; the oxychloride becomes the most insoluble solid compound, and hence the substance which restricts the solubility of the cupric ion, only at the lowest test levels of chlorides and when, at the same time, the ratio between the concentrations of $\left[\mathrm{NH}_{3}\right]_{\mathrm{t}}$ and $[\mathrm{Cu}]_{\mathrm{t}}$ is less than 2 . When the solubility of $\mathrm{Cu}(\mathrm{II})$ diammine chloride establishes that of the cupric ion, the concentration of chlorides hardly affects this solubility, which in practice is essentially 
determined by the concentration of total ammonia in solution and, at each temperature, all the solubility data for the different total chloride levels can be represented in an $\left[\mathrm{NH}_{3}\right]_{\text {Total }}[\mathrm{Cu}]_{\text {Total }}$ by only one mean curve, with almost no error for practical purposes. On the other hand, when the solubility of the cupric ion is controlled by that of its oxychloride, the concentration of chloride has a strong influence.

The results obtained in the present work confirm the previous ones. For the conditions here studied, total chloride concentrations 1 to 4 molal, the $\mathrm{Cu}$ (II) solubility is also restricted by either the solubility of its diammine chloride or its oxychloride. In this case, however, the solubility behaviour of these two solid compounds is here quite different. As the experimental results show, the cupric oxychloride is generally the solid phase whose solubility regulates that of the cupric ion. Only, at the highest test levels of chlorides and when, at the same time, the temperature is low (25 ${ }^{\circ} \mathrm{C}$ ) and the ratio between the concentrations of $\left[\mathrm{NH}_{3}\right]_{\text {Total }}$ and $[\mathrm{Cu}]_{\text {Total }}$ is higher than 2, the cupric diammine chloride becomes the most insoluble compound, and in consequence, the one which regulates the $\mathrm{Cu}$ (II) solubility.

As it was exposed before, in the conditions studied here, cupric hydroxychloride crystallizes in two different crystalline forms. However, no relation between experimental conditions and the crystalline form precipitated could be found.

The theoretical treatment of $\mathrm{Cu}$ (II) solubility in ammoniacal ammonium chloride solution can be done keeping in mind all the different complexes that are formed in this medium. In the model developed in (9), it was considered that the $\mathrm{Cu}(\mathrm{II})$ in solution is distributed, besides the ionic form $\mathrm{Cu}^{2+}$, in form of chloride complexes $\mathrm{CuCl}_{\mathrm{n}}{ }^{2-n}$, ammonia complexes $\mathrm{Cu}(\mathrm{NH} 3)_{\mathrm{n}}{ }^{2+}$ and ammonia chloride complexes $\mathrm{Cu}(\mathrm{NH} 3)_{4-\mathrm{n}} \mathrm{Cl}_{\mathrm{n}}{ }^{2-n}$, where $n$ takes values from 1 to 4 . The total copper concentration, $[\mathrm{Cu}]_{\text {Total }}$, is the addition of the concentrations of all the ionic species in which $\mathrm{Cu}$ (II) is distributed. The same balance can be done for the total chloride and ammonia concentrations. The model assumes the existence of eighteen unknown concentrations: $\left[\mathrm{Cu}^{2+}\right], \quad\left[\mathrm{NH}_{3}\right], \quad\left[\mathrm{Cl}^{-}\right], \quad\left[\mathrm{H}^{+}\right], \quad\left[\mathrm{Cu}\left(\mathrm{NH}_{3}\right)^{2+}\right]$, $\left[\mathrm{Cu}\left(\mathrm{NH}_{3}\right)_{2}{ }^{2+}\right],\left[\mathrm{Cu}\left(\mathrm{NH}_{3}\right)_{3}{ }^{2+}\right],\left[\mathrm{Cu}\left(\mathrm{NH}_{3}\right)_{4}{ }^{2+}\right]$, $\left[\mathrm{CuCl}^{+}\right],\left[\mathrm{CuCl}_{2}\right],\left[\mathrm{CuCl}_{3}^{-}\right],\left[\mathrm{CuCl}_{4}^{2-}\right],\left[\mathrm{CuCl}_{3}\left(\mathrm{NH}_{3}\right)^{-}\right]$, $\left[\mathrm{CuCl}\left(\mathrm{NH}_{3}\right)_{3}{ }^{+}\right],\left[\mathrm{NH}_{4}{ }^{+}\right],\left[\mathrm{NH}_{3}\right]_{\text {Total }},[\mathrm{Cu}]_{\text {Total }}$, and $[\mathrm{Cl}]_{\text {Total }}$. To calculate these concentrations, it can be used the twelve equations for the chemical equilibriums of the complex formation and the solubility products, as well as the four corresponding to the material and loading balances. With the use of appropriate complex formation constants values from the literature, corresponding in each case to the ionic strength studied, the total concentrations of copper, ammonia and chloride can be estimated. In this way, it is possible to determine the solubility concentrations at equilibrium.

In the above mentioned paper (9), the predicted solubility curves obtained with this model fitted well with experimental data obtained for total chloride concentration higher than 5.0 molal, proving the validity of the model for the satisfactory description of the system solubility for these conditions.

For the experimental conditions here studied, total chloride concentration lower than 5.0 molal, it is not posible to make a similar comparative analysis for all the experimental solubility data. This is due to the absence of literature data on complex formation constants for many of the tested ionic strengths. For this reason, this analysis has been only made for the two higher values (3,0 and 4,0 molal) of total chloride concentration tested, using the same equilibrium constant data that were selected in (9) from the literature (11-14) for ionic strength 5-6 (Table II). This approach was assumed, considering that the value of concentration-based formation constant changes slowly (8 and 14) as ionic strength increases above $3 \mathrm{~mol} / \mathrm{kg}$. Elsewhere, the hydroxychloride solubility product value was estimated from the experimental solubility data, using the model such as was made in previous works (8 and 9). The value of the hydroxychloride $\mathrm{Cu}(\mathrm{OH})_{1,5} \mathrm{Cl}_{0,5}$ solubility product so calculated (log $P_{\mathrm{s}}=-16,65$ at $25^{\circ} \mathrm{C}$ ) has the same magnitude order although it is slightly lower than the value reported in (11) $\left(\log P_{\mathrm{s}}=-17,3\right.$ at $\left.25^{\circ} \mathrm{C}\right)$ for ionic strength zero.

The solubility isotherms of $\mathrm{Cu}$ (II) hydroxychloride and chloride diammine predicted with the model for a temperature of $25^{\circ} \mathrm{C}$ have been represented in figure 1 for the 4,0 molal chloride level. As it can be seen, the two isotherms cross at one point, which defines the point of the solubility curve where the solid phase in equilibrium with the solution, either the hydroxychloride or the diammine chloride, changes. The $\mathrm{Cu}$ (II) solubility curve for this total concentration of chloride and temperature is composed of two different sections; each one belongs to one of the isotherms (continuous lines), and corresponds to that with the least solubility. The experimental points from table I obtained at this level of chloride concentration are also represented in figure 1 along with the predicted curves. As it can be seen, there is a good fit between the experimental points and the predicted curves. This agreement confirms the validity of the theorical model for the conditions here tested, providing a rational prediction model for $\mathrm{Cu}$ (II) solubility in the $\mathrm{CuCl}_{2}-\mathrm{NH}_{4} \mathrm{Cl}-\mathrm{NH}_{3}-\mathrm{H}_{2} \mathrm{O}$ system, as well as for which is, in each case, the solid compound in equilibrium with the solution. 
Table II.- Formation constants and thermodynamic data used in the model

TABLA II.- Valores de las constantes usados en el modelo

\begin{tabular}{|c|c|c|c|c|}
\hline Formation constants & $\begin{array}{l}\log \\
\beta_{298}\end{array}$ & $\underset{\mathrm{kJ} / \mathrm{mol}}{\mathrm{H}}$ & $\begin{array}{l}\text { Ionic } \\
\text { Strength }\end{array}$ & Ref. \\
\hline$\beta_{1}=\left[\mathrm{Cu}\left(\mathrm{NH}_{3}\right)^{2+}\right] /\left[\mathrm{Cu}^{2+}\right]\left[\mathrm{NH}_{3}\right]$ & 4,47 & $-23,0$ & 6,0 & $13(*)$ \\
\hline$B_{2}=\left[\mathrm{Cu}\left(\mathrm{NH}_{3}\right)_{2}{ }^{2+}\right] /\left[\mathrm{Cu}^{2+}\right]\left[\mathrm{NH}_{3}\right]^{2}$ & 8,29 & $-46,4$ & 6,0 & $13^{(*)}$ \\
\hline$B_{3}=\left[\mathrm{Cu}\left(\mathrm{NH}_{3}\right)_{3}{ }^{2+}\right] /\left[\mathrm{Cu}^{2+}\right]\left[\mathrm{NH}_{3}\right]^{3}$ & 11,50 & $-69,4$ & 6,0 & $13^{(*)}$ \\
\hline$\left.B_{4}=\left[\mathrm{Cu}\left(\mathrm{NH}_{3}\right)_{4}\right)^{2+}\right] /\left[\mathrm{Cu}^{2+}\right]\left[\mathrm{NH}_{3}\right]^{4}$ & 13,95 & $-92,0$ & 6,0 & $13^{(*)}$ \\
\hline$B_{1}{ }^{\prime}=\left[\mathrm{CuCl}^{+}\right] /\left[\mathrm{Cu}^{2+}\right]\left[\mathrm{Cl}^{-}\right]$ & 0,60 & 16,6 & 5,0 & 14 \\
\hline $\mathrm{B}_{2}{ }^{\prime}=\left[\mathrm{CuCl}_{2}\right] /\left[\mathrm{Cu}^{2+}\right]\left[\mathrm{Cl}^{-}\right]^{2}$ & 0,67 & 22,0 & 5,0 & 14 \\
\hline $\mathrm{B}_{3}{ }^{\prime}=\left[\mathrm{CuCl}_{3}^{-}\right] /\left[\mathrm{Cu}^{2}\right]\left[\mathrm{Cl}^{-}\right]^{3}$ & 0,30 & 0,0 & 5,0 & 14 \\
\hline$\left.B_{4}{ }^{\prime}=\left[\mathrm{CuCl}_{4}{ }^{2-}\right]\right] /\left[\mathrm{Cu}^{2+}\right]\left[\mathrm{Cl}^{-}\right]^{4}$ & $-0,64$ & 0,0 & 5,0 & 14 \\
\hline $\begin{aligned} \beta_{3,1}= & {\left[\mathrm{CuCl}_{3}\left(\mathrm{NH}_{3}\right)^{-}\right] /\left[\mathrm{Cu}^{2+}\right] } \\
& {\left[\mathrm{Cl}^{-}\right]^{3}\left[\mathrm{NH}_{3}\right] }\end{aligned}$ & 3,62 & 26,9 & $5-8$ & 9 \\
\hline $\begin{aligned} B_{1,3}= & {\left[\mathrm{CuCl}\left(\mathrm{NH}_{3}\right)_{3}+\right] /\left[\mathrm{Cu}^{2+}\right] } \\
& {\left[\mathrm{Cl}^{-}\right]\left[\mathrm{NH}_{3}\right]^{3} }\end{aligned}$ & 11,73 & $-56,0$ & $5-8$ & 9 \\
\hline $\mathrm{P}_{\mathrm{s}}=\left[\mathrm{Cu}(\mathrm{NH})_{3}{ }^{2+}\right]\left[\mathrm{Cl}^{-}\right]^{2}$ & $-1,70$ & 0,0 & $5-8$ & 9 \\
\hline $\mathrm{P}_{\mathrm{s}}^{\prime}=\left[\mathrm{Cu}^{2+}\right]\left[\mathrm{Cl}^{-}\right]^{0.5}\left[\mathrm{OH}^{-}\right]^{1.5}$ & $-16,65$ & 11,0 & $3-4$ & $(* *)$ \\
\hline $\mathrm{K}_{\mathrm{a}}=\left[\mathrm{NH}_{4}^{+}\right] /\left[\mathrm{NH}_{3}\right]\left[\mathrm{H}^{+}\right]$ & 9,80 & $-56,5$ & 5,0 & 11 \\
\hline $\mathrm{K}_{\mathrm{w}}=\left[\mathrm{H}_{2} \mathrm{O}\right] /\left[\mathrm{H}^{+}\right]\left[\mathrm{OH}^{-}\right]$ & 14,18 & $-54,7$ & 3,0 & 11 \\
\hline
\end{tabular}

(*) Calculated values for a 6 molal saline concentration from the expression given in (13) for a $\mathrm{NH}_{4} \mathrm{NO}_{3}$ medium $\left(\log K_{\mathrm{n}}=\log K_{\mathrm{n}}{ }^{0}\right.$ $+0,08 \mathrm{C}$, being $\log \beta_{\mathrm{n}}=\Sigma \log K_{\mathrm{i}}$, from $i=1$ to $i=n$ ).

(*) Valores calculados para una concentración salina 6 molal con la expresión dada en (13) para un medio $\mathrm{NH}_{4} \mathrm{NO}_{3}\left(\log K_{\mathrm{n}}=\log K_{\mathrm{n}}{ }^{0}\right.$ $+0,08 \mathrm{C}$, siendo $\log \beta_{\mathrm{n}}=\Sigma \log K_{\mathrm{i}}$, from $i=1$ to $\left.i=n\right)$.

$(* *)$ Estimated values from experimental solubility data.

(**) Valores estimados a partir de los datos experimentales de solubilidad.

In figure 2, the cupric hydroxychloride solubility curve predicted for a total chloride concentration 3,0 molal at $25^{\circ} \mathrm{C}$ has been represented. Along with this predicted curve, the figure also illustrates the experimental points of solubility (listed in table I) obtained for this same total chloride concentration and temperature. As can be seen, there is also a very good fit between the predicted solubility curve and the experimental points. In this figure, experimental points obtained for this same total chloride concentration but at a temperature of $60{ }^{\circ} \mathrm{C}$ have been also included. As can be seen, the temperature has scarce influence on cupric hydroxychloride solubility. This behaviour, together with the strong influence of the temperature on the cupric diammine chloride solubility, satisfactorily explains the change of compound in the solid phase with the temperature

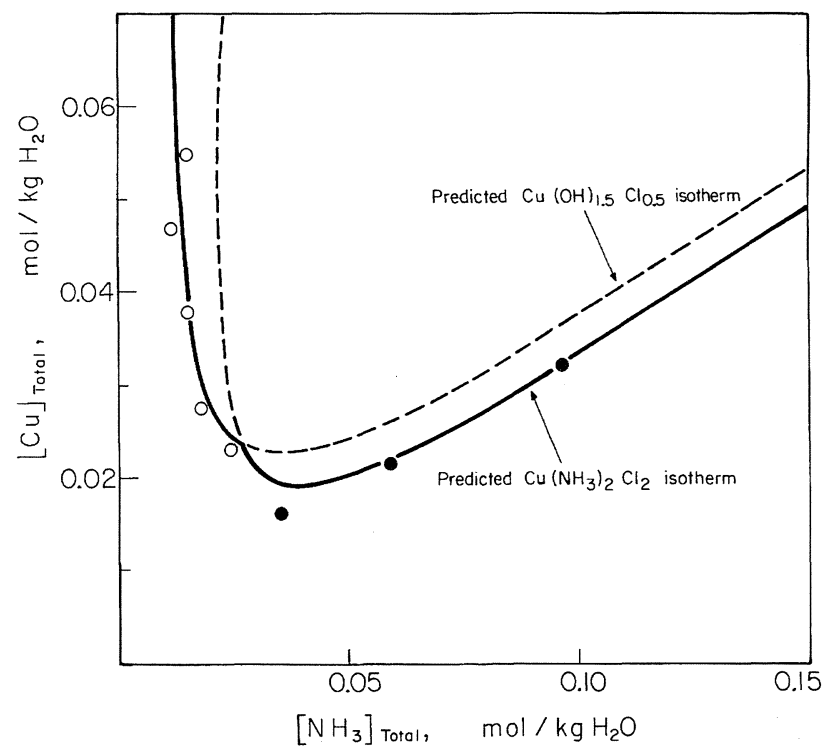

FIG. 1.- $\mathrm{Cu}(\mathrm{II})$ solubility as a function of total ammonia concentration in the system $\mathrm{CuCl}_{2}-\mathrm{NH}_{4} \mathrm{Cl}-$ $\mathrm{NH}_{3}-\mathrm{H}_{2} \mathrm{O}$ at $25{ }^{\circ} \mathrm{C}$ for a total chloride concentration 4,0 molal.

Open symbols: $\mathrm{Cu}(\mathrm{OH})_{1,5} \mathrm{Cl}_{0,5}$ (solid phase).

Full symbols: $\mathrm{Cu}\left(\mathrm{NH}_{3}\right)_{2} \mathrm{Cl}_{2}$ (solid phase).

FIG. 1.- Solubilidad del Cu(II) en función de la concentración total de amoniaco en el sistema $\mathrm{CuCl}_{2}-\mathrm{NH}_{4} \mathrm{Cl}-\mathrm{NH}_{3}-\mathrm{H}_{2} \mathrm{O}$ a $25{ }^{\circ} \mathrm{C}$ para una concentración de cloruro total 4,0 molal.

Símbolos vacíos: $\mathrm{Cu}(\mathrm{OH})_{15} \mathrm{Cl}_{0,5}$ (fase sólida).

Símbolos llenos: $\mathrm{Cu}\left(\mathrm{NH}_{3}\right)_{2} \mathrm{Cl}_{2}$ (fase sólida).

increases. As experimental results show, this phenomenon is observed for a total chloride concentration value of 4,0 molal and when the ratio $\left[\mathrm{NH}_{3}\right]_{\text {Total }} /[\mathrm{Cu}]_{\text {Total }}$ is higher than 2 . In these conditions, the solid compound in equilibrium at 25 ${ }^{\circ} \mathrm{C}$ with the solution is the cupric diammine chloride, but changes to the hydroxychloride when the temperature increases to $60^{\circ} \mathrm{C}$.

\section{CONCLUSIONS}

In the range of ammonium chloride studied ( 1 to 4 molal), the solubility of $\mathrm{Cu}(\mathrm{II})$ in ammoniacal aqueous solutions of ammonium chloride is restricted by either the solubility of the $\mathrm{Cu}$ (II) diammine chloride or the $\mathrm{Cu}(\mathrm{II})$ hydroxychloride. The hydroxychloride is generally the solid phase whose solubility regulates that of the cupric ion. The diammine chloride becomes the most insoluble compound, and hence the substance which restricts the solubility of cupric ion, only at the highest test level of chloride and when, at the same time, the ratio between the concentrations of $\left[\mathrm{NH}_{3}\right]_{\text {Total }}$ and $[\mathrm{Cu}]_{\text {Total }}$ is higher than 2 . 


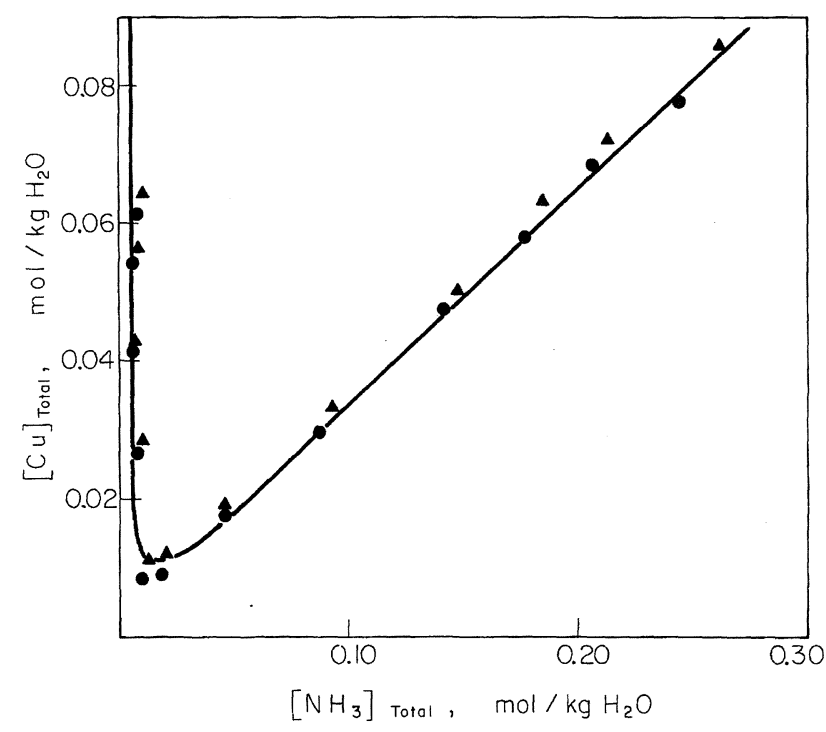

FIG. 2.- $\mathrm{Cu}(\mathrm{II})$ solubility as a function of total ammonia concentration in the system $\mathrm{CuCl}_{2}-\mathrm{NH}_{4} \mathrm{Cl}$ $\mathrm{NH}_{3}-\mathrm{H}_{2} \mathrm{O}$ for a total chloride concentration 3,0 molal. Continuous line: Solubility predicted curve of $\mathrm{Cu}(\mathrm{OH})_{1,5} \mathrm{Cl}_{0,5}$ at $25^{\circ} \mathrm{C}$ obtained using the model for the total chloride concentration 3,0 molal.

Symbols: Experimental results $\bullet$ at 25 and $\boldsymbol{\Delta}$ at $60^{\circ} \mathrm{C}$.

FIG. 2.-Solubilidad del Cu(II) en función de la concentración total de amoniaco en el sistema $\mathrm{CuCl}{ }_{2}-\mathrm{NH}_{4} \mathrm{Cl}-\mathrm{NH}_{3}-\mathrm{H}_{2} \mathrm{O}$ para una concentración total de cloruro 3,0 molal.

Línea continua: Curva teórica de solubilidad del $\mathrm{Cu}(\mathrm{OH})_{1,5} \mathrm{Cl}_{0,5}$ a $25{ }^{\circ} \mathrm{C}$ obtenida usando el modelo para una concentración total de cloruro 3,0 molal. Símbolos: Resultados experimentales • a 25 y a $60{ }^{\circ} \mathrm{C}$.

When the solubility of the cupric ion is controlled by that of its hydroxychloride, the concentration of chloride has a strong influence while the temperature scarcely influences. This behavior represents the opposite to that found for the diammine chloride solubility (9).

There is a very good fit between experimental data and solubility isotherms predicted by the theoretical model developed in (9). This agreement confirms the validity of this model, which also describes satisfactorily the solubility of the cupric ion under the conditions here tested.

\section{Acknowledgements}

The authors gratefully acknowledge the DGICYT (Spain) for its financial support in Project AMB93-0284.

\section{REFERENCES}

(1) Limpo, J.L, Figueiredo, J.M., Amer, S. and Luis, A. Hydrometallurgy, 28, 1992: 149-161.

(2) LIMPO, J.L. 4th Brite-Euram Conference. Commission of the European Communities, DG XII. Sevilla, mayo de 1992.

(3) Limpo, J.L, Figueiredo, J.M., Amer, S. and Luis, A. Spanish Pat. № 8,902,487 (1989).

(4) De la Cuadra, A. and Limpo, J.L.. Quim. Ind. (Madrid), 38 (1), 1992: 27-34.

(5) Limpo, J.L., Amer, S., Figueiredo, J.M. and Novais, A. Proc. 2nd Intern. Conf. on Hydrometallurgy. ICHM ' 92. Changsha (China). International Academic Publishers. Vol. 1. Pekin 1992: 302-309.

(6) Figueiredo, J.M. Novais, A., Limpo, J.L. and AmER, S. Proc. Intern. Symp. World Zinc '93. AusIMM. Hobart, October 1993: 333-339.

(7) LIMPO, J.L., Luis, A. and GómEz, C. Hydrometallurgy, 28, 1992: 163-178

(8) LIMPO, J.L. and LuIs, A. Hydrometallurgy, 32, 1993: $247-$ 260.

(9) Limpo, J.L., Luis, A. and CRistina, M.C. Rev. Metal. Madrid, 29 (1), 1993: 27-36.

(10) Powder Diffraction File Inorganic Phases (Hanavalt). Ed. International Centre for Diffraction Data. U.S.A., 1988.

(11) Smith, R.M. and Martell, A.E. Critical Stability Constants. Vol. 4: Inorganic Complexes. Ed. Plenum Press. New York, 1976.

(12) MARTEll, E.A. and SmIth, R.M. Critical Stability Constants. Volume 5: 1st Sup. Ed. Plenum Press. New York, 1982.

(13) Bjerrum, J., Schwarzenback, G. and Sillen, L.G. Stability Constants. Part II: Inorganic Ligands. Ed. Chem. Soc. London, 1958.

(14) McDonald, G.W. and LANGer, S.H. Metall. Trans. B, 14, 1983: 559-570. 